\title{
LICHEN GROWTH ON AN ACTIVE MEDIAL MORAINE, JOTUNHEIMEN, NORWAY
}

\author{
By J. A. Matthews \\ (Department of Geography, University of Edinburgh, Edinburgh EHI INR, Scotland)
}

\begin{abstract}
Abundant specimens of lichens, including Rhizocarpon geographicum, are reported from an active medial moraine on Storbreen, southern Norway. The size and distribution of two crustose and two foliose species are described. Inferences are made regarding the age, origin and population dynamics of the lichens. Some implications of the observations for lichenometric dating and use of lichens as indicators of moraine stability are discussed.

RÉsumé. Croissance des lichens sur une moraine médiane active, Jotunheimen, Norvège. D'abondants exemplaires de lichens, parmi lesquels Rhizocarpon geographicum, ont été trouvés sur une moraine médiane active sur le Storbreen dans le sud de la Norvège. La taille et la distribution de deux espèces à croûtes et de deux espèces à feuilles sont décrites. Des déductions sont faites sur l'âge, l'origine et la dynamique des populations de lichens. On discute quelques conséquences des observations faites concernant le datage lichenométrique et l'usage des lichens comme indicateurs de la stabilité des moraines.

Zusammenfassung. Flechtenwachstum auf einer aktiven Mittel-Moräne, Jotunheimen, Norwegen. Vielfältige Arten von Flechten, einschliesslich Rhizocarpon geographicum, finden sich auf einer aktiven Mittel-Moräne auf dem Storbreen in Süd-Norwegen. Grösse und Verteilung zweier Krustosen und zweier foliosen Arten werden beschrieben. Schlüsse auf das Alter, die Herkunft und Verbreitungsdynamik der Flechten werden gezogen. Einige Auswirkungen der Beobachtungen für die lichenometrische Datierung und die Bedeutung von Flechten als Indikatoren für die Stabilität von Moränen werden diskutiert.
\end{abstract}

\section{INTRODUCTION}

During the summer of 1970 abundant specimens of several species of lichen were discovered on an active medial moraine of Storbreen, west Jotunheimen, Norway. The same species were also found on the pro-glacial area immediately in front of the glacier-snout margin.

The presence of lichens on and immediately in front of a retreating glacier is of considerable interest as it has previously been assumed that lichen growth is unusual, if not impossible, in such locations. Only exceptionally have cases been reported where one or a few individuals have been found in varying degrees of contact with ice (Goldthwait, I96o; Beschel, I96r[a]; Andrews and Webber, I964; Østrem, I965; Reger and Péwé, r969). Indeed, Beschel (196r [b], p. го5o) has stated:

"Boulders deposited on the ice surface in the ablation zone will easily fall into crevasses but, in exceptional circumstances, may remain on the surface until they are deposited at the snout. It can hardly be expected, however, that after a ride on a glacier, an originally lichen-covered rock will be redeposited with an orientation permitting the continual growth of plants. Examining some one hundred glaciers the writer could never find any lichens on boulders or bedrock in front of receding ice."

This paper describes some observations on the distribution and size of the four commonest lichen species, offers some speculations on their age, origin and population dynamics, and points to some implications for lichenometric dating and the use of lichens as indicators of moraine stability.

Two crustose and two foliose species were studied (Fig. I): yellow-green individuals of Rhizocarpon geographicum agg.; a grey crustose Lecidea sp. (probably L. subsorediza Lynge); the grey foliose Umbilicaria cylindrica (L.) Del. ex Duby; the black foliose $U$. cf. torrefacta (Lightf.) Schrad. More positive identification of two of the species was not possible because of immaturity of individuals. Very small individuals of Lecanora intricata (Ach.) Ach., Rhizocarpon grande (Flörke ex Flot.) Arnold and Aspicilia sp. were also present in smaller numbers. 


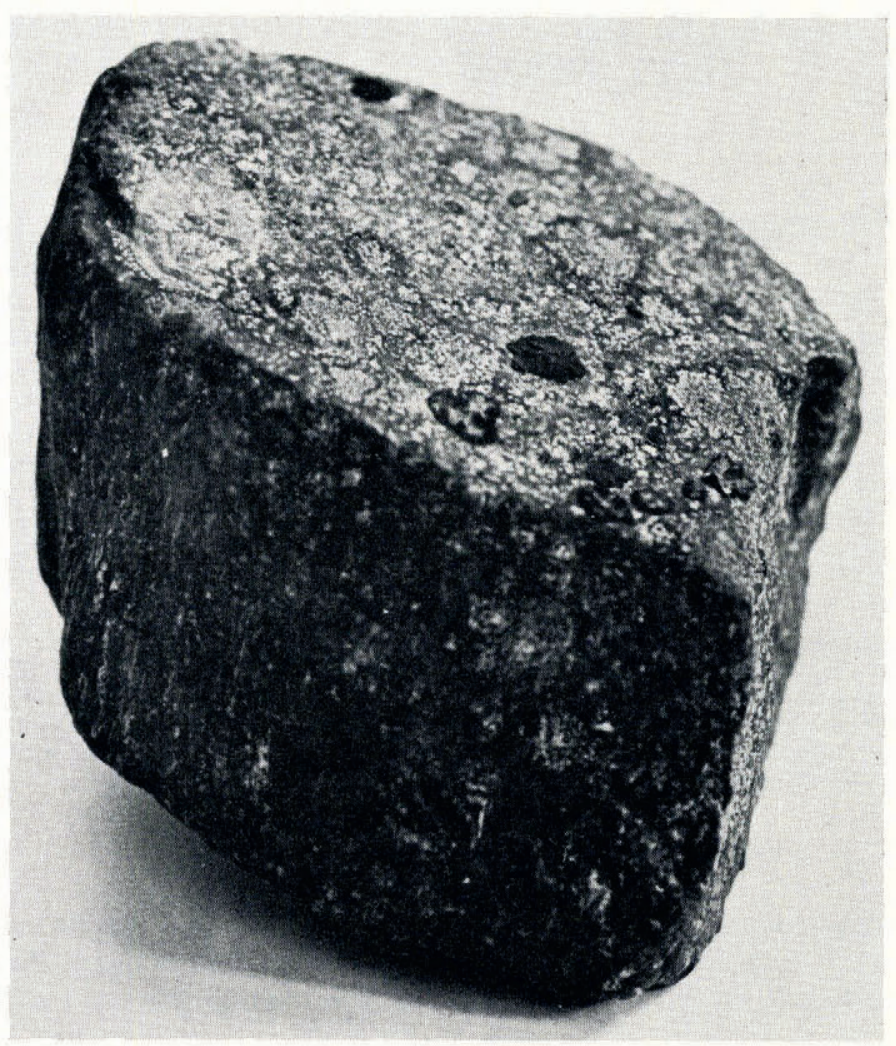

Fig. I. Lichen-covered rock from the large medial moraine near the snout of Storbreen (site $C)$. The rock is about $15 \mathrm{~cm}$ long. The grey foliose individuals with black ciliate margins are $U$. cylindrica. $U$. cf. torrefacta is uniformly black. These foliose individuals are less than $20 \mathrm{~mm}$ in diameter. The greater part of the upper rock surface is covered with the grey crustose Lecidea sp. up to about $30 \mathrm{~mm}$ diameter and smaller specimens of $R$. geographicum.

\section{LICHEN DISTRIBUTION AND SIZE VARIATION}

Sites were searched for lichens on two medial moraines and on adjacent sections of the proglacial area (Figs. 2 and 3). At each of seven sites, A to G, $2 \mathrm{~m}$ by $8 \mathrm{~m}$ plots were searched for the largest lichens. At site $\mathrm{B} 400 \mathrm{~m}^{2}$ were searched in this way while at the remaining sites $800 \mathrm{~m}^{2}$ were searched, plots being arranged in strips $8 \mathrm{~m}$ wide (Fig. 3). The greatest diameter of the largest lichen of each of the four species studied was measured in each plot with dial calipers (to the nearest o.o I $\mathrm{mm}$ ).

Results are summarized in size-frequency histograms (Fig. 4). No lichens were found at sites $\mathrm{E}, \mathrm{F}$ and $\mathrm{G}$. The largest individuals of crustose species were found on the medial moraine under the nunatak (site A). Here $R$. geographicum reached $33.5 \mathrm{~mm}$ and Lecidea sp. $44.4 \mathrm{~mm}$ in diameter. These figures reflect the relatively slow rate of growth of $R$. geographicum, a fact noted elsewhere (e.g. Stork, I963) and illustrated also by the relatively large diameters reached by Lecidea sp. on the inactive moraines in front of Storbreen. U. cylindrica and $U$. cf. torrefacta reached 49.3 and $43.0 \mathrm{~mm}$, respectively, both at site B.

For each species the statistical significance of apparent differences in the size-frequency histograms between adjacent sites was tested by two non-parametric statistical tests (Table I). First, the Mann-Whitney " $U$ " was used to test the hypothesis that differences in size of largest lichens between sites are significant. Secondly, $\chi^{2}$, based on a $2 \times 2$ contingency table, was 


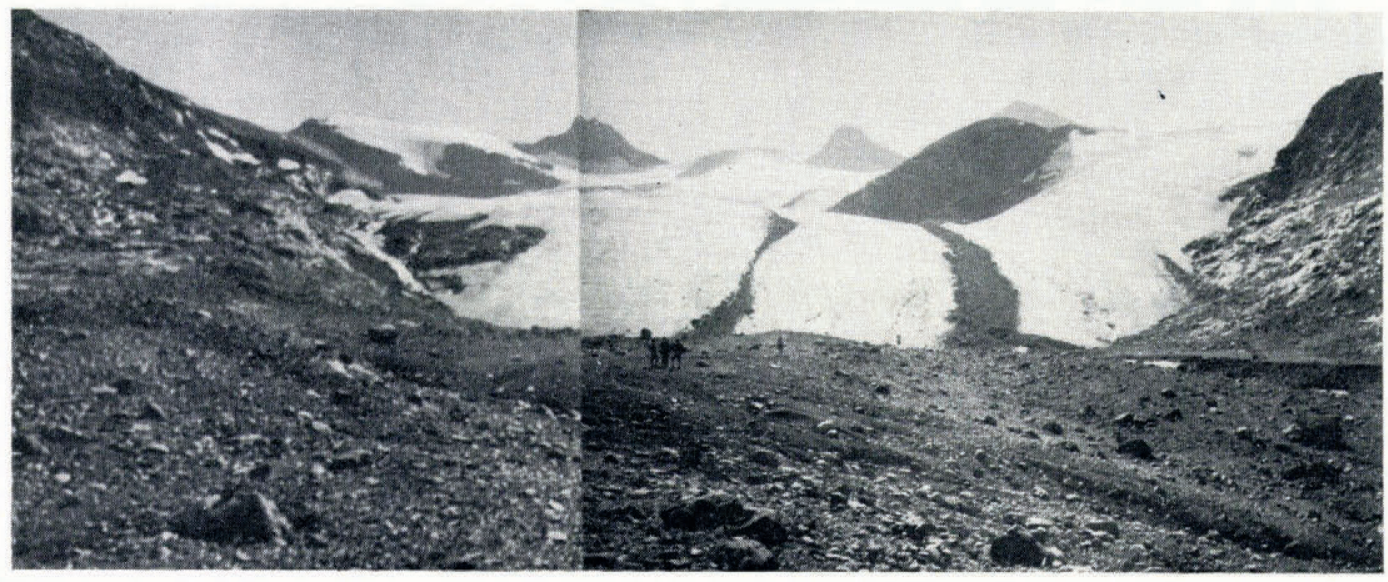

Fig. 2. The snout of Storbreen-i-Leirdalen. The larger medial moraine (right) extends for about I $\mathrm{km}$ from the glacier snout to the foot of the nunatak but the smaller moraine disappears less than $500 \mathrm{~m}$ from the snout. The pro-glacial area forms an almost flat plain for about $400 \mathrm{~m}$ in front of the glacier. Heights of the snout, nunatak and surrounding peaks are 1350 , I 675 and over 2 ooo $\mathrm{m}$, respectively. (Photograph by 7. C. Leigh, I97 I.)

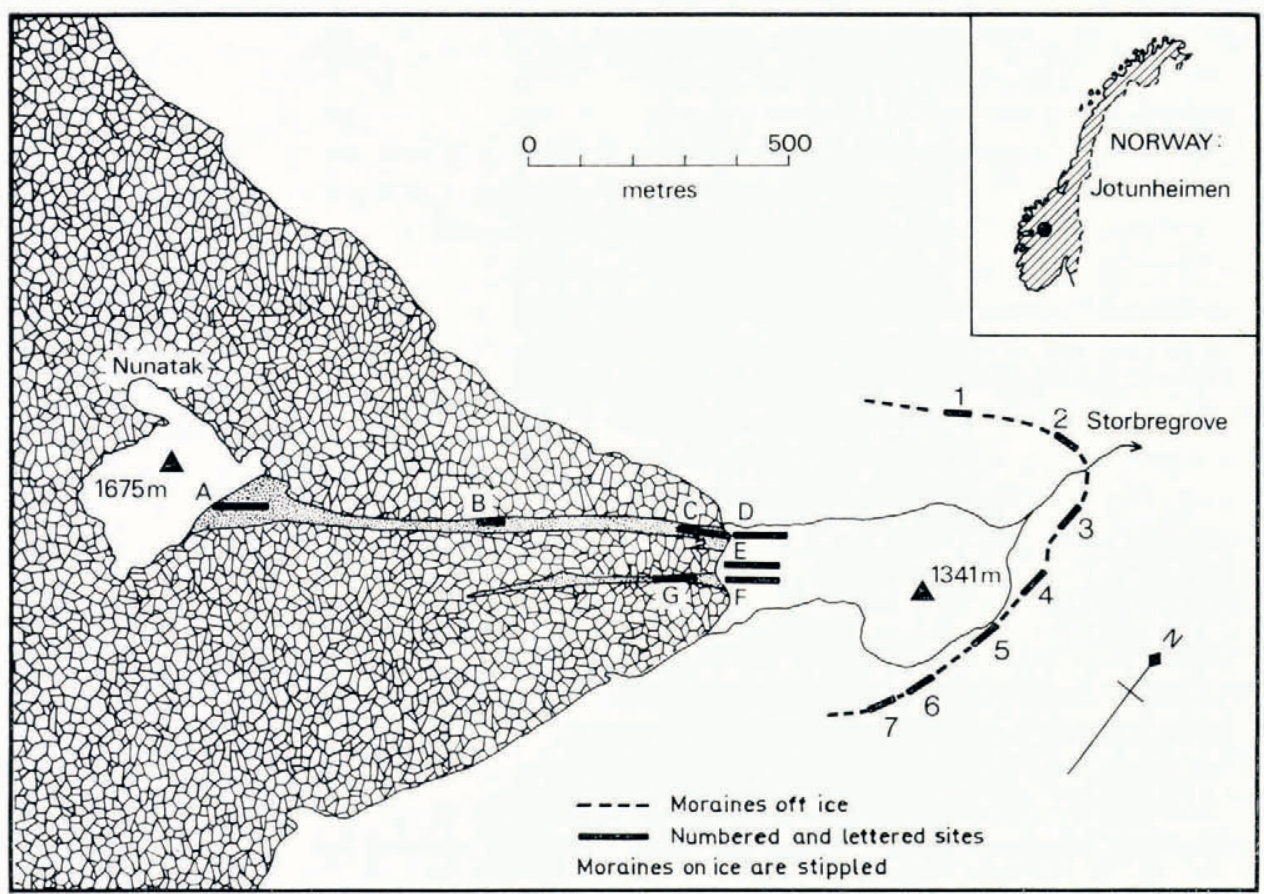

Fig. 3. Simplified map of the Storbreen snout showing active medial moraines (stippled), the inactive moraine dating from $1925-28$ dashed line) and the location of measurement sites (solid black rectangles labelled $A$ to $G$ and $I-7$ ). 
used to test whether the frequencies of presence and absence of lichens differ significantly between sites. In the case of the $\chi^{2}$ test, $\chi^{2}$ corrected for continuity was used as recommended by Siegel (1956). The significance of $U$ was assessed using $Z$, derived from $U$, again as recommended by Siegel (1956).

\begin{tabular}{|c|c|c|}
\hline Species & Sites compared & $\chi^{2}$ \\
\hline R. geographicum & $\begin{array}{l}\text { A-B } \\
\text { B-C } \\
\text { A-C } \\
\text { C-D }\end{array}$ & $\begin{array}{c}* \\
* * \\
* * \\
* *\end{array}$ \\
\hline Lecidea sp. & $\begin{array}{l}\text { A-B } \\
\text { B-C } \\
\text { A-C } \\
\text { C-D }\end{array}$ & $\begin{array}{l}* * \\
\mathrm{~ns} \\
* * \\
* *\end{array}$ \\
\hline U. cylindrica & $\begin{array}{l}\mathrm{A}-\mathrm{B} \\
\mathrm{B}-\mathrm{C} \\
\mathrm{A}-\mathrm{C} \\
\mathrm{C}-\mathrm{D}\end{array}$ & $\begin{array}{c}\mathrm{ns} \\
* \\
\mathrm{~ns} \\
* *\end{array}$ \\
\hline$U$. cf. torrefacta & $\begin{array}{l}\mathrm{A}-\mathrm{B} \\
\mathrm{B}-\mathrm{C} \\
\mathrm{A}-\mathrm{C} \\
\mathrm{C}-\mathrm{D}\end{array}$ & $\begin{array}{c}\mathrm{ns} \\
\mathrm{ns} \\
* \\
* *\end{array}$ \\
\hline
\end{tabular}

Significant differences are indicated as $* *(p=0.01)$ and $*(p=0.05)$; differences probably of no significance are indicated as $\mathrm{ns}(p>0.05)$.

On the medial moraine, the crustose species show a steady decline in size of individuals as well as in the proportion of occupied plots from sites A to C. The foliose species, on the other hand, at first show a significant increase in size between sites $\mathrm{A}$ and $\mathrm{B}$ followed by a reduction in size between sites B and $\mathrm{C}$. The proportion of occupied sites shows relatively less variation than in the case of the crustose species, apparently caused by differences in ecology of the species. The foliose species commonly favour more exposed sites where they give a black appearance to ridges and inactive moraine tops throughout the area. It would seem that the foliose species are relatively tolerant of the morainic substrate under exposed conditions in the centre of the medial moraine. All species show a greater proportion of occupied plots in front of the glacier snout, at site $\mathrm{D}$, than on the medial moraine, at site $\mathrm{C}$. In the case of $R$. geographicum and $U$. cylindrica there are also significant differences in lichen size, the lichens being larger at site $\mathrm{D}$.

\section{LIGHEN AGE, ORIGIN AND GROWTH ON THE MEDIAL MORAINE}

The maximum age of the largest lichens can be estimated from the size of lichens on surfaces of known age. The actual age is somewhat younger as an initial period of time is necessary for establishment on a freshly exposed surface. According to one study in northern Sweden (Stork, I963), about 10-20 years is necessary for the establishment of $R$. geographicum in that area, although establishment may be more rapid in more favourable situations such as along stream beds (Curry, I969). A substrate of known age is provided by the youngest inactive moraine of the Storbreen foreland, which dates from the I920's when most glaciers in southern Norway advanced. It is most likely that this particular moraine dates from the years $19^{2} 5^{-28}$ (Liestøl, 1967) and is therefore approximately 45 years old. The largest specimen of $R$. geographicum on the moraine was $30.5 \mathrm{~mm}$, a figure established from searching $2800 \mathrm{~m}^{2}$ in a similar manner to the procedures outlined above. 
The largest specimen of $R$. geographicum on active moraine was $33.5 \mathrm{~mm}$. Unless conditions for lichen growth, e.g. micro-climate, are very different on the active as compared with the inactive moraine, the largest lichen on the former can be little more than $5^{\circ}$ years old. The largest specimen on the pro-glacial area (site D) was about half this size ( $16.6 \mathrm{~mm})$, indicating a maximum age of 25 years. Most individuals encountered were smaller than mentioned above. It is therefore reasonable to assume an age of less than 25 years for the majority of the lichens. It can also be assumed that the largest individuals of the other species do not differ markedly in age from those of $R$. geographicum.

Some lichens at site A may have begun growth on nunatak rock and survived subsequent incorporation into the medial moraine. Lichens from the other sites, particularly smaller individuals and specimens at sites furthest from the nunatak, are unlikely to have originated on the nunatak as the rate of transport by the glacier is inconsistent with the youth of the lichens. Velocity of ice movement on Storbreen varies from $5.9 \mathrm{~cm} \mathrm{~d}^{-1}$ to a few millimetres per day (Liestøl, I 967 ). The former figure gives a minimum length of time for movement of a block from the nunatak to the snout of the order of 40 years. The actual time will be considerably longer than this due to reduction in velocity towards the snout. It would seem therefore that even the largest specimens at site $\mathrm{C}$ must have become established directly on active medial moraine.

Colonization by lichens depends on a suitable substrate remaining exposed for a sufficiently long period of time for weathering of the surface. Herein lies the probable explanation for the absence of lichens from site $\mathrm{G}$ on the smaller medial moraine. The larger medial moraine is visible on an old photograph taken in 1908 (Liestøl, I967), thus allowing at least 63 years for colonization at site $\mathrm{C}$, given sufficiently slow transport by the glacier and sufficient stability of blocks during transport. There is no reason to believe that the smaller moraine is more unstable or faster moving than the larger one but it has not been visible for as long and does not have the possibility of such well-weathered blocks, some derived from the nunatak, forming part of its fabric.

Reduction in the number of occupied plots from sites $\mathrm{A}$ to $\mathrm{C}$ can be explained by progressive thinning of the lichen populations in response to instability of the substrate. Some evidence of thinning of populations is provided by discoloured and partly disintegrated thalli which were occasionally observed on the under surfaces of blocks. During movement towards the snout many blocks are turned over or at least displaced enough to change the microclimate of the lichens. In addition to glacier-ice movement, ablation in the summer months causes lowering of the ice surface and disturbance of blocks. The instability effect of ablation increases towards the snout whereas the effect of velocity decreases. Benedict ( 1967 ) suggested that $R$. geographicum can survive at least 5 years on stones that have been overturned in rocky areas but that thalli are destroyed by a similar period of burial in contact with moist soil. The crustose species encountered here, including $R$. geographicum, would seem to be most affected in this manner. The foliose species appear to be more resistant to instability in this environment, as evinced by the increase in size from sites $\mathrm{A}$ to $\mathrm{B}$ and no significant change in the number of occupied plots. In the case of the crustose species, rate of establishment and growth is exceeded by rate of destruction, whereas for the foliose species the reverse case holds.

\section{THE QUESTION OF LIGHEN SURVIVAL OF DEPOSITION}

Records of the retreat of Storbreen taken by members of the Norsk Polarinstitutt show that the parts of the pro-glacial area occupied by sites D, E and F were exposed from beneath retreating ice during the years 1962 to 1970 , giving a maximum age for the exposed substrate of less than ro years. As it has been shown above that some lichens at site D have an age of approximately 25 years, survival of deposition from the medial moraine is beyond doubt. 


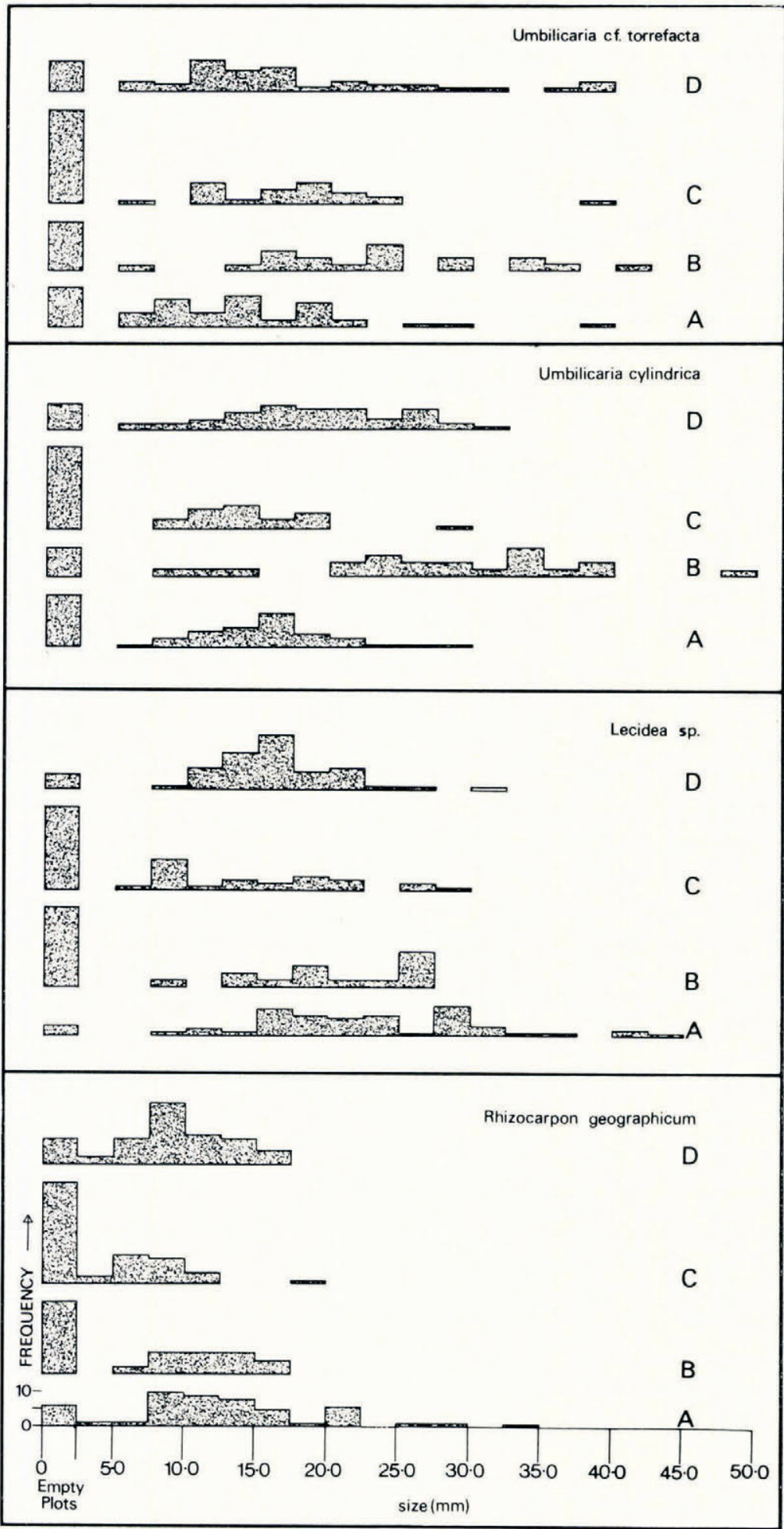

Fig. 4. 
Furthermore, $R$. geographicum and $U$. cylindrica show significant increases in size when proglacial site $\mathrm{D}$ is compared with the medial moraine site $\mathrm{C}$. Absence of lichens at sites $\mathrm{E}$ and $\mathrm{F}$ can only strengthen this conclusion.

While the increase in size of $R$. geographicum and $U$. cylindrica (Fig. 4; Table I, $U$ ) indicates a continuation of growth after deposition, the significantly greater proportion of occupied to unoccupied plots at site D compared with site C, for all four species (Fig. 4; Table I, $\chi^{2}$ ), is evidence for the establishment of lichens immediately in front of the retreating ice. If lichens can establish directly on the active medial moraine, then immediate establishment on deposited blocks in the pro-glacial area is to be expected. The only alternative to immediate establishment is that very small individuals, not visible at site $\mathrm{C}$, grew sufficiently large to be visible during and immediately after deposition.

\section{IMPLICATIONS FOR LICHENOMETRY AND ESTIMATION OF MORAINE STABILITY}

Lichenometric dating, usually involving $R$. geographicum, is based on the existence of a known numerical relationship between thallus size and surface age. On exposure, a surface is assumed to be lichen-free and to be subject to what might be termed the normal process of colonization. If, in the case of a deglaciated surface, lichens are present at the time of deglaciation and continue to grow or colonize immediately after exposure, then the technique is subject to a possible error dependent on the size of the lichens involved.

The possible error introduced at Storbreen has been demonstrated to be an overestimate of age by up to 25 years. This could be of some significance in dating neoglacial moraines in areas such as south Norway where most glaciers, including Storbreen, have a series of moraines deposited since $c$. I $75^{\circ}$ (Hoel and Werenskiold, I962). The error over this time scale could be as much as $10 \%$, enough to confuse the ages of near-contemporaneous moraines. In areas where much longer time scales are involved this error would be far less significant.

The probable error is less than indicated if one takes into account the small part of the pro-glacial area possibly influenced by lichens surviving deposition from the medial moraine. An empirical test of the actual error was carried out at Storbreen by measuring largest lichens at seven sites distributed around the $1925^{-28}$ moraine (Fig. 3). Strips of moraine $5^{0} \mathrm{~m}$ by $8 \mathrm{~m}$ were searched at each site for abnormally large lichens. The largest lichens at the seven sites were found to be 2 I.2, 29.2, 2 I.0, 24. I, 27.6, 30.4 and $30.5 \mathrm{~mm}$, from sites I to 7 respectively, none of which can be regarded as exceptionally large. In this case the error can be considered negligible, particularly as two of the largest figures are from valley-side sites which could not have been "contaminated" by specimens from the medial moraine.

In view of the possible error, it is unwise to search only one locality on each surface to be dated and equally unwise to rely on the single largest thallus for dating purposes. Averaging of the five largest individuals, each from a separate locality on the surface to be dated, as has been most usual in Scandinavian work (e.g. Stork, I963; Andersen and Sollid, I971; Mottershead and White, I972), is to be favoured from this point of view. Use of number of lichens per rock or percentage cover of lichens (Orwin, I970) also reduces the possibility of error introduced by one or a few anomalously large lichens.

Use of lichens as indicators of moraine stability assumes that instability of the substrate prevents establishment and continual growth. The presence of lichens on the medial moraine, which is undoubtedly unstable, necessitates revision of this assumption. On the basis of the

Fig. 4 (left). Size-frequency histograms of largest lichens for four species at four sites, A to D. The first class (left) represents vasant plots. The remaining classes are at $2.5 \mathrm{~mm}$ intervals, beginning with the class $2.5-4.99 \mathrm{~mm}$. Individuals smaller than $2.5 \mathrm{~mm}$ become difficult to identify with certainty and some vacant plots may in fact contain such individuals. Very small individuals may also have been missed by the search procedure. Frequency at site $B$ has been doubled to facilitate visual comparison. 
evidence above, two provisos are required: first, that relative stability is indicated, and secondly, that the morainic blocks are sufficiently weathered. The increase in colonization following deposition of blocks at site $\mathrm{D}$ reflects an increase in stability of the substrate, while absence of colonization at sites $\mathrm{E}$ and $\mathrm{F}$ reflects the less weathered nature of blocks exposed from beneath the retreating glacier and deposited from the smaller medial moraine. In the present case, all four species studied appear to tolerate a degree of instability with the foliose species being able to tolerate the greater instability. Blanket use of lichens as indicators of a stable moraine would therefore seem to be unjustified. The ecology of the species concerned, the degree of weathering of the substrate and the degree of stability of the substrate should all be considered in any estimation of moraine stability based on lichen cover.

\section{Conclusion}

It has been shown that the distribution and sizes of lichens on the medial moraine and on the pro-glacial area of Storbreen are consistent with the following ideas: (I) Some lichens probably began life on nunatak rock and survived incorporation into the larger medial moraine; (2) Some lichens continued to grow on the larger medial moraine after direct establishment; (3) It is unlikely that any lichens from the nunatak or site A survived transport on the glacier to be deposited in the pro-glacial area; (4) Some lichens survived deposition in the pro-glacial area; (5) Some lichens colonized the pro-glacial area immediately after ice retreat, on blocks which were weathered on the medial moraine.

Although the lichens found on and in front of Storbreen were relatively abundant, their occurrence remains an isolated case and, while the possible effect on lichenometric dating is to lead to an overestimate of morainic age, the realization of this effect in practice would be most unusual. The ecological significance of lichen growth on an active moraine is clear, however, and it indicates the direction in which ideas should change regarding lichens as indicators of moraine stability.

\section{Acknowledgements}

I am grateful to the members of the Jotunheimen Research Expedition, I970, who helped carry out this work, particularly J. C. Leigh and P. J. Parkinson. The following helped to finance the expedition: the Central Research Fund of the University of London; King's College, London; Queen Mary College, London; Goldsmiths' Company and the Royal Society. The work was carried out while the author held a Natural Environment Research Council Studentship at King's College, London. I am also grateful to O. Liestøl, who provided records of the retreat of Storbreen in recent years, B. Coppins, who identified the species measured, Dr W. W. Newey for his comments on the original draft of the manuscript, and to A. Carson Clark, I. McKay and Mrs P. Robertson for cartography, photography and typing, respectively.

MS. received 8 November 1972

\section{REFERENCES}

Andersen, J. L., and Sollid, J. L. I971. Glacial chronology and glacial geomorphology in the marginal zones of the glaciers Midtdalsbreen and Nigardsbreen, south Norway. Norsk Geografisk Tidsskrift, Bd. 25, Ht. I, p. I-38.

Andrews, J. T., and Webber, P. J. 1964. A lichenometrical study of the northwestern margin of the Barnes Ice Cap: a geomorphological technique. Geographical Bulletin (Ottawa), No. 22, p. 80-104.

Benedict, J. B. 1967 . Recent glacial history of an alpine area in the Colorado Front Range, U.S.A. I. Establishing a lichen-growth curve. Fournal of Glaciology, Vol. 6, No. 48, p. 81 7-32.

Beschel, R. E. I96r [a]. Botany and some remarks on the history of vegetation and glacierization. (In Müller, F., and others. Facobsen-McGill Arctic Research Expedition to Axel Heiberg Island, Queen Elizabeth Islands. Preliminary report of 1959-1960, by F. Müller and members of the expedition. Montreal, McGill University, p. 179-99.) 
Beschel, R. E. 196r [b]. Dating rock surfaces by lichen growth and its application to glaciology and physiography (lichenometry). (In Raasch, G. O., ed. Geology of the Arctic: proceedings of the first international symposium on Arctic geology held in Calgary, Alberta, January $I_{1-13}, 1960$. Toronto, University of Toronto Press, Vol. 2, p. I044-62.)

Curry, R. R. 1969. Holocene climatic and glacial history of the central Sierra Nevada, California. Geological Society of America. Special Paper No. 123, p. 1-47.

Goldthwait, R. P. 1960. Study of ice cliff glacier in Nunatarssuaq area, Greenland. U.S. Cold Regions Research and Engineering Laboratory. Technical Report 39.

Hoel, A., and Werenskiold, W. I962. Glaciers and snowfields in Norway. Norsk Polarinstitutt. Skrifter, Nr. I I4.

Liestøl, O. 1967. Storbreen glacier in Jotunheimen, Norway. Norsk Polarinstitutt. Skrifter, Nr. 141.

Mottershead, D. N., and White, I. D. I972. The lichenometric dating of glacier recession, Tunsbergdal, southern Norway. Geografiska Annaler, Vol. 54A, No. 2, p. 47-52.

Orwin, J. 1970. Lichen succession on recently deposited rock surfaces. New Zealand Journal of Botany, Vol. 8, No. 4, p. $45^{2-77}$.

Østrem, G. 1965. Problems of dating ice-cored moraines. Geografiska Annaler, Vol. 47A, No. I, p. I-38.

Reger, R. D., and Péwé, T. L. 1969. Lichenometric dating in the central Alaska Range. (In Péwé, T. L., ed. The periglacial environment, past and present. Montreal, McGill-Queen's University Press [and] Arctic Institute of North America, p. 223-47.)

Siegel, S. 1956. Nonparametric statistics for the behavioral sciences. New York, McGraw-Hill (in collaboration with Kogakusha Co. Ltd., Tokyo). (International Student Edition.)

Stork, A. 1963. Plant immigration in front of retreating glaciers, with examples from the Kebnekajse area, northern Sweden. Geografiska Annaler, Vol. 45, No. 1, p. I-22. 